\title{
Melting of major Glaciers in the western Himalayas: evidence of climatic changes from long term MSU derived tropospheric temperature trend (1979-2008)
}

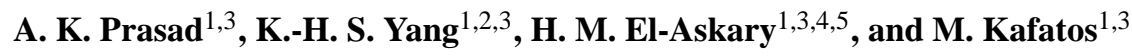 \\ ${ }^{1}$ Department of Physics, Computational Science and Engineering, Schmid College of Science, Chapman University, Orange, \\ CA 92866, USA \\ ${ }^{2}$ Department of Biological Sciences, Schmid College of Science, Chapman University, Orange, CA 92866, USA \\ ${ }^{3}$ Center of Excellence in Earth Observing, Chapman University, Orange, CA 92866, USA \\ ${ }^{4}$ Department of Environmental Sciences, Faculty of Science, Alexandria University, Moharem Bek, Alexandria, 21522, Egypt \\ ${ }^{5}$ National Authority for Remote Sensing and Space Science (NARSS), Cairo, Egypt
}

Received: 16 April 2009 - Revised: 19 August 2009 - Accepted: 9 September 2009 - Published: 11 December 2009

\begin{abstract}
Global warming or the increase of the surface and atmospheric temperatures of the Earth, is increasingly discernible in the polar, sub-polar and major land glacial areas. The Himalayan and Tibetan Plateau Glaciers, which are the largest glaciers outside of the Polar Regions, are showing a large-scale decrease of snow cover and an extensive glacial retreat. These glaciers such as Siachen and Gangotri are a major water resource for Asia as they feed major rivers such as the Indus, Ganga and Brahmaputra. Due to scarcity of ground measuring stations, the long-term observations of atmospheric temperatures acquired from the Microwave Sounding Unit (MSU) since 1979-2008 is highly useful. The lower and middle tropospheric temperature trend based on 30 years of MSU data shows warming of the Northern Hemisphere's midlatitude regions. The mean month-to-month warming (up to $0.048 \pm 0.026^{\circ} \mathrm{K} /$ year or $1.44^{\circ} \mathrm{K}$ over 30 years) of the mid troposphere (near surface over the high altitude Himalayas and Tibetan Plateau) is prominent and statistically significant at a 95\% confidence interval. Though the mean annual warming trend over the Himalayas $\left(0.016 \pm 0.005^{\circ} \mathrm{K} /\right.$ year $)$, and Tibetan Plateau $\left(0.008 \pm 0.006^{\circ} \mathrm{K} /\right.$ year $)$ is positive, the month to month warming trend is higher (by $2-3$ times, positive and significant) only over a period of six months (December to May). The factors responsible for the reversal of this trend from June to November are discussed here. The inequality in the magnitude of the warming trends of the troposphere between the western and eastern
\end{abstract}

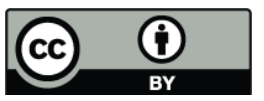

Correspondence to: A. K. Prasad (aprasad@chapman.edu)
Himalayas and the IG (Indo-Gangetic) plains is attributed to the differences in increased aerosol loading (due to dust storms) over these regions. The monthly mean lowertropospheric MSU-derived temperature trend over the IG plains (dust sink region; up to $0.032 \pm 0.027^{\circ} \mathrm{K} /$ year) and dust source regions (Sahara desert, Middle East, Arabian region, Afghanistan-Iran-Pakistan and Thar Desert regions; up to $0.068 \pm 0.033^{\circ} \mathrm{K} /$ year) also shows a similar pattern of month-to-month oscillation and six months of enhanced and a statistically significant warming trend. The enhanced warming trend during the winter and pre-monsoon months (December-May) may accelerate glacial melt. The unequal distribution of the warming trend over the year is discussed in this study and is partially attributed to a number of controlling factors such as sunlight duration, $\mathrm{CO}_{2}$ trends over the region (2003-2008), water vapor and aerosol distribution.

Keywords. Atmospheric composition and structure (Aerosols and particles) - Meteorology and atmospheric dynamics (Climatology) - Radio science (Remote sensing)

\section{Introduction}

The Himalayan glaciers, the largest body of ice outside of the polar icecaps (Kulkarni et al., 2005), are a source of water for major rivers of Asia such as the Indus, Ganga and Brahmaputra. A large fraction of the world's population ( $>1 / 6$ th or over a billion people) inhabits the IG (Indo-Gangetic) plains (Pakistan, India, parts of Nepal, Bangladesh, China) and depend on the melt-water and rainfall from these resources. In recent years, the Himalayan glaciers are found to be among the fastest receding glaciers in the world thereby

Published by Copernicus Publications on behalf of the European Geosciences Union. 
affecting the discharge of the Indus, Ganga, Brahmaputra, Mekong, Thanlwin, Yangtze, and the Yellow rivers. The rate of retreat is believed to be approximately $10-15 \mathrm{~m} /$ year (33-49 ft/year) (WWF, 2005). The annual rate of retreat is known to vary widely but with an increasing trend. For instance, satellite data show that the Parbati glacier located in the western Himalayas retreated by $97 \mathrm{~m}$ from 2000-2001 compared to $22 \mathrm{~m}$ from $1998-2000$. It is observed that a decrease of $578 \mathrm{~m}$ occurred in the last century (between 1990 and 2001) (Kulkarni et al., 2005). The large-scale retreat or mass loss of the Himalayan glaciers has a potentially huge impact on the available freshwater resources throughout Asia (Krishna, 2005; Rees and Collins, 2006; Kehrwald et al., 2008; Winiger et al., 2005), which may cause major socio-economic problems. The analysis of the ice-cores and snow from Tibet-Himalaya region show recent climate changes and influence of dust storms and anthropogenic activities (Qin et al., 2000; Kang et al., 2001; Xu et al., 2007; Lee et al., 2008).

\subsection{Objectives of the present study}

Long-term studies of temperature variation are crucial to our understanding of climate change. The longest available record of tropospheric (lower and middle) temperature data from satellite sensors (MSU-AMSU) from 1979-2008 have been used to analyze the trends of lower and middle tropospheric temperatures over the Himalayan region, Tibetan Plateau, adjacent IG plains and major dust source regions in the northern mid-latitudes that are known to affect the western Himalayas and IG plains (Prasad and Singh, 2007a, b; Kayetha et al., 2007). The annual and month-to-month MSU-derived warming trend of the troposphere and their connection with other major factors that control atmospheric temperature (such as $\mathrm{CO}_{2}$, aerosols, water vapor, sunlight) is largely unknown over the region. The role played by the variation of sunlight, aerosols and other greenhouse gases such as $\mathrm{CO}_{2}$ and water vapor in the temperature modulation over the dust source, sink, and snow cover regions need to be investigated. Free tropospheric $\mathrm{CO}_{2}(\mathrm{ppm})$ data and length of sunlight variation (in minutes), in conjunction with the warming trend, have been analyzed to study $\mathrm{CO}_{2}$ and sunlight variation. The differences in the warming trends of the western and eastern Himalayan regions and the IG plains is very important in view of the known contrast in aerosol loading over the region and the influence of the western dust source regions. The impact of monsoon rainfall and the corresponding increase in moisture in the atmosphere on the temperature trend is discussed. The month-to-month warming trend over major dust source regions in Asia and the effect of other controlling factors have been investigated qualitatively. An overview of the impact of these controlling factors over the observed warming trend is presented in this study.

\subsection{Major Himalayan glaciers: melting and long term changes}

\subsubsection{Siachen and Gangotri Glacier}

The Siachen Glacier, the second largest glacier known outside of the polar and sub-polar regions (Kulkarni et al., 2005; Upadhyay, 2009), is located in the western Himalayas. The Gangotri glacier, a cluster of glaciers, is the second largest glacier in the Himalayas. The glacial melt contributes 29\% of the annual flow at Devprayag (elevation $690 \mathrm{~m}$, near the Foothills of the Himalayas) (Jain, 2008). They feed major rivers of the region and supplies hundreds of millions of people with fresh water (Table 1). The rate of retreat of these glaciers have been found to be higher during recent decades (Raina and Sangewar, 2007; Jain, 2008)

\subsubsection{Tibetan Plateau and Indian summer monsoon}

The Tibetan Plateau, also known as the roof of the world due to its base height residing in the free troposphere, receives large amounts of solar heat flux. The strong heating of the mountainous regions of Tibet creates a strong heat contrast in the mid-tropospheric altitudes. The development of a strong North-South heat gradient during pre-monsoon months across the Tibetan plateau, IG plains and the Bay of Bengal, is known to influence the Asian and Indian monsoon circulation patterns (Shekhar and Dash, 2005; Lau et al., 2006; Lau and Kim, 2006). General Circulation Model (GCM) experiments show that Tibetan snow cover and snowfall during pre-monsoon months (April) affects the monsoon rainfall over India. An inverse snow-monsoon relationship is observed between monsoon rainfall over India and premonsoon snowfall over the Tibet Plateau. A positive snow mass anomaly (snow fall) over Tibet during pre-monsoon months tends to lessen the temperature gradient and affects the circulation pattern of wind and moisture leading to a weak monsoon (Ose, 1996). Most of the Tibetan Glaciers are showing signs of accelerated retreat in recent decades (Yao et al., 2007). The knowledge of a long-term month-to-month temperature (warming or cooling) trend over Tibetan Plateau is essential as it not only explains the snow cover loss or gain but also strong or weak Indian Summer monsoons.

\subsection{Impact of global warming on glaciers}

Global temperatures have increased by $0.6 \pm 0.2^{\circ} \mathrm{C}$ since 1990 (Lozan et al., 2001). The MSU channel Temperature Lower Troposphere (TLT) and MSU/AMSU channel Temperature Middle Troposphere (TMT) show global temperature increase of $0.156^{\circ} \mathrm{K} /$ decade and $0.091^{\circ} \mathrm{K} /$ decade, respectively. Global warming is believed to be the cause of large-scale glacial retreat around the world (Oerlemans, 2005). The Tibetan Plateau shows an annual warming rate of $0.16^{\circ} \mathrm{C} /$ decade and a winter warming trend of $0.32^{\circ} \mathrm{C} /$ decade (Liu and Chen, 2000). The Tibetan Plateau also shows 
Table 1. Characteristics of the major glaciers and glacier-snow covered regions in the Himalayas and Tibetan Plateau.

\begin{tabular}{|c|c|c|c|c|}
\hline $\begin{array}{l}\text { Glacier or re- } \\
\text { gion }\end{array}$ & Location & Major rivers & Rate of retreat & Reference \\
\hline Siachen & $\begin{array}{l}\text { Eastern Karakoram region } \\
\text { (northern Ladakh) }\end{array}$ & Nubra, Shyok, and Indus & $\begin{array}{l}\text { Higher during 20th century } \\
\text { (1929-1958) as compared } \\
\text { to } 1862-1909\end{array}$ & Raina and Sangewar (2007) \\
\hline Gangotri & Western Himalayas & $\begin{array}{l}\text { Ganga and its numerous } \\
\text { tributaries, Brahmaputra }\end{array}$ & $\begin{array}{l}\text { In recent decades, 22- } \\
27 \text { m/year }\end{array}$ & Jain (2008) \\
\hline $\begin{array}{l}\text { Himachal } \\
\text { Glacier region }\end{array}$ & Western Himalayas & & $\begin{array}{l}\text { Increased rate of glacial } \\
\text { ice loss during } 1999-2003 \\
\text { compared to 1977-1999 } \\
\text { (Mass-balance studies: } \\
\text { ground and satellite based } \\
\text { data) }\end{array}$ & Berthier et al. (2007) \\
\hline $\begin{array}{l}\text { Chenab, Par- } \\
\text { bati and Baspa } \\
\text { basins }\end{array}$ & $\begin{array}{l}\text { Western Himalayas } \\
\text { (analysis of } 466 \text { glaciers) }\end{array}$ & & $\begin{array}{l}\text { Overall reduction in glacial } \\
\text { area from } 2077 \mathrm{sq} . \mathrm{km} \text { (in } \\
\text { 1962) to } 1628 \mathrm{sq} . \mathrm{km} \text { (at } \\
\text { present) and an overall } \\
\text { deglaciation of } 21 \% \\
\text { Total glacial area has re- }\end{array}$ & Kulkarni et al. (2007) \\
\hline \multirow[t]{3}{*}{ Glaciers in China } & & & ceded by about $5.5 \%$ since & Li et al. (2008) \\
\hline & Qinghai-Tibetan Plateau & & $\begin{array}{l}\text { Models predict a } 26.7 \% \\
\text { shrinkage in glacial area by } \\
2050\end{array}$ & \\
\hline & & & $\begin{array}{l}\text { Degradation of the per- } \\
\text { mafrost could reach up to } \\
33 \% \text { to } 50 \% \text { by } 2100\end{array}$ & \\
\hline $\begin{array}{l}\text { North slope of } \\
\text { Qomolangma }\end{array}$ & Mount Everest & & $5.5-9.5 \mathrm{~m} \mathrm{a}^{-1}$ since 1960 & Jiawen et al. (2006) \\
\hline
\end{tabular}

a decrease in the length of the snow cover season by 23 days at elevations between $4000-6000 \mathrm{~m}$ a.s.l. with early snowmelt occurring at elevations up to $5500 \mathrm{~m}$ a.s.l. (Rikiishi and Nakasato, 2006). Temperature data collected from 125 stations across India show an increasing temperature trend of $0.36^{\circ} \mathrm{C}$ (western India) and $1.06^{\circ} \mathrm{C}$ (southern India) but a declining trend of $-0.38^{\circ} \mathrm{C}$ over the IG plains per 100 years. The annual mean (mean maxima) temperatures have increased at the rate of $0.42^{\circ} \mathrm{C}\left(0.92^{\circ} \mathrm{C}\right)$ per 100 years (Arora et al., 2005). During the winter, the seasonal mean temperature has increased by $1.1^{\circ} \mathrm{C}$ per 100 years (Arora et al., 2005). Shrestha et al. (1999) observed warming trend of 0.068 to $0.128^{\circ} \mathrm{C}$ per year in most of the Middle Mountain and Himalayan regions (from 1977-1994).

The impact of climate change, in the form of warming of the region, is noticeable in the change of snow cover and mass balance (of snow and glacier) studies over the Himalayan and Tibetan Glaciers (Kulkarni and Bahuguna, 2002; Kulkarni and Alex, 2003; Kulkarni et al., 2002, 2005; Berthier 2007; Berthier et al., 2007; Kehrwald et al., 2008). Between 1962-2001, Kulkarni et al. (2007) observed an overall $21 \%$ decline in the glacial area of 466 glaciers in the Himalayan basins (Baspa, Parbati and Chenab) (Table 1).
Visible data (images) from the earliest available records from satellites (Landsat series, since 1972) show substantial changes in snow cover over the region (Fig. 1). The longterm data acquired from ground stations that measure surface temperature, snowfall, and precipitation are not widely available in for the high altitude Himalayan and Tibet regions. Surface air temperature data from the National Centers for Environmental Prediction/National Center for Atmospheric Research (NCEP/NCAR) models show regional warming in those areas. The NCEP/NCAR reanalysis data over the Himalayas/Tibetan Plateau can capture the synoptic-scale variability in temperature and pressure, but the values are systematically lower than the observations (Xie et al., 2007).

\subsection{Influence of dust storms and anthropogenic pollu- tion over Himalayan and Tibet Glaciers}

Ice cores from Himalaya-Tibet region show history of dust storm and anthropogenic activities over the region (Kang et al., 2000; Duan et al., 2007; Xu et al., 2007; Lee et al., 2008; Kehrwald et al., 2008). Geochemical isotope analyses of icecores from the western and central Himalayan glaciers show the presence of dust as well as summer monsoon signals. The ice cores from the Dasuopu glacier (central Himalaya) show 
signals of dust deposition during the pre-monsoon months (1988-1997) which coincide with periods of dust storm activity involving the long-range transport of dust from the arid and desert regions of the west and the north (Kang et al., 2000). The ice-cores from the Dasuopu glacier show summer monsoon and pre-monsoon dust signals in seasonal variation of delta $\mathrm{O}^{18}$ and major-ion concentrations $\left(\mathrm{Ca}^{2+}, \mathrm{Mg}^{2+}\right.$ and $\mathrm{SO}^{4-}$ ) (Kang et al., 2000).

An ice-core-derived sulfate record from the Dasuopu glacier, for the years 1000-1997 shows an increased anthropogenic influence starting around 1930, while the sulfate levels are found to be low and relatively constant prior to 1870. The sulfate concentrations in ice-cores have doubled since the 1970s, which implies increased anthropogenic sulfate emissions over the source regions and its transport and deposition over the Himalayan Glaciers (Duan et al., 2007).

Further, radioactivity analyses of ice cores taken from the Naimona'nyi Glacier in the Himalayas (Tibet) lack signals from the atmospheric thermonuclear bomb testing that occurred during the 1950s and 1960s. This may imply that there has been no net accumulation of snow over the highest glaciers (6050 masl) in Tibet between 1950 and 2006 (Kehrwald et al., 2008).

The westerly winds during the pre-monsoon month bring large amounts of dust from Africa, Arabia, Middle East, Afghanistan, and the Thar desert regions over the IG plains and the Himalayan regions (Prasad et al., 2006a; Prasad and Singh, 2007a; Singh et al., 2004). The western Himalayas and the IG plains are affected more than the eastern regions (Prasad and Singh, 2007b). Monsoon circulation, wind, temperature and precipitation patterns, which are different between the western and eastern regions, affect the glacier retreat pattern over the western and eastern Himalayas and Tibet plateau (He et al., 2003). The palaeoclimatic records from the Himalayas and the adjacent regions suggest that, on millennial timescales, both the South Asian monsoon and the mid-latitude westerlies affect the Himalayan glacier fluctuations (Benn and Owen, 1998). The dust and anthropogenic pollution (black carbon) during pre-monsoon months over the IG plains, extending up to Himalayas and Tibetan Plateau may cause enhanced heating, affecting the temperature gradient and the monsoon circulation pattern (Lau et al., 2006; Lau and Kim, 2006). Gautam et al. (2009) found warming of $1.419^{\circ} \mathrm{K}$ (extrapolated to 30 years for comparison from original trend of $0.0473^{\circ} \mathrm{K} /$ year for 29 year period) during pre-monsoon season over the northern India $\left(25-35^{\circ} \mathrm{N}\right.$, $69-82^{\circ}$ E). Further, Gautam et al. (2009) found warming of $2.79^{\circ} \mathrm{K}$ (extrapolated from $2.7^{\circ} \mathrm{K}$ in 29 years) over the mid troposphere for period 1979-2008 during pre-monsoon season over Himalayan-Gangetic region. Some of these results have been compared here.

\subsection{Solar forcing of the climate and greenhouse gases $\left(\mathrm{CO}_{2}\right.$, water vapor $)$}

Solar forcing of the climate is an important controlling force and it increases uncertainty towards assessing global warming effects due to anthropogenic pollution $\left(\mathrm{CO}_{2}\right.$, black carbon, aerosols and other greenhouse gases). Solar irradiance variations, over a multi-year time period and over seasons (within a year), is likely to produce a positive or negative feedback on interactions with different components that enhances or suppresses global warming. The seasonal cycles of sunlight variation have been studied here to partially explain the warming trend observed from MSU data.

\section{Data sources}

\subsection{MSU temperature data: major issues and multi- decadal trends}

Multi-decadal data (late 1978 to 2009) based on the Microwave Sounding Unit (MSU) and the Advanced Microwave Sounding Unit (AMSU) are available from various sources. The satellite based MSU measurements have been taken since late 1978, while the AMSU was launched in 1998. A combination of inter-calibrated and combined data from MSU and AMSU provide long-term atmospheric temperature records (lower, middle, near tropospause, and lower stratosphere). The major component of the measured brightness temperature (channels 1 and 4) from MSU comes from the thermal emission of atmospheric oxygen. Channel 1 corresponds to the lower troposphere while channel 4 corresponds to the lower stratosphere. The MSU data suffer from a number of inter-calibration issues, time and diurnal biases. Several groups (Remote Sensing Systems (RSS), the University of Maryland (UMD), the University of Alabama at Huntsville (UAH), the NOAA National Environmental Satellite, Data, and Information Service (NOAA/NESDIS)) have merged the data available from these MSU/AMSU instruments to produce a long-term atmospheric temperature record (Christy et al., 2000, 2003; Grody et al., 2004; Mears et al., 2002, 2003; Mears and Wentz, 2009; Prabhakara et al., 2000; Vinnikov et al., 2005; Zou et al., 2006).

We have used the atmospheric temperature (microwave lower and mid tropospheric) records from the MSU and AMSU-derived temperature data that are available from Remote Sensing Systems (RSS). The entire dataset (19792008) is available online at the RSS website http://www. ssmi.com (latest v3.2; accessed online on 9 March 2009). The specific MSU and AMSU channels that are combined to form new datasets used in this study, namely TMT and TLT are given in Mears and Wentz (2009). The temperature weighting functions that describe the relative contribution of each atmospheric layer to the observed brightness temperature (Tb) is also discussed in Mears and Wentz (2009). 


\section{Major Rivers and Glacier-snow Extent}

(a)
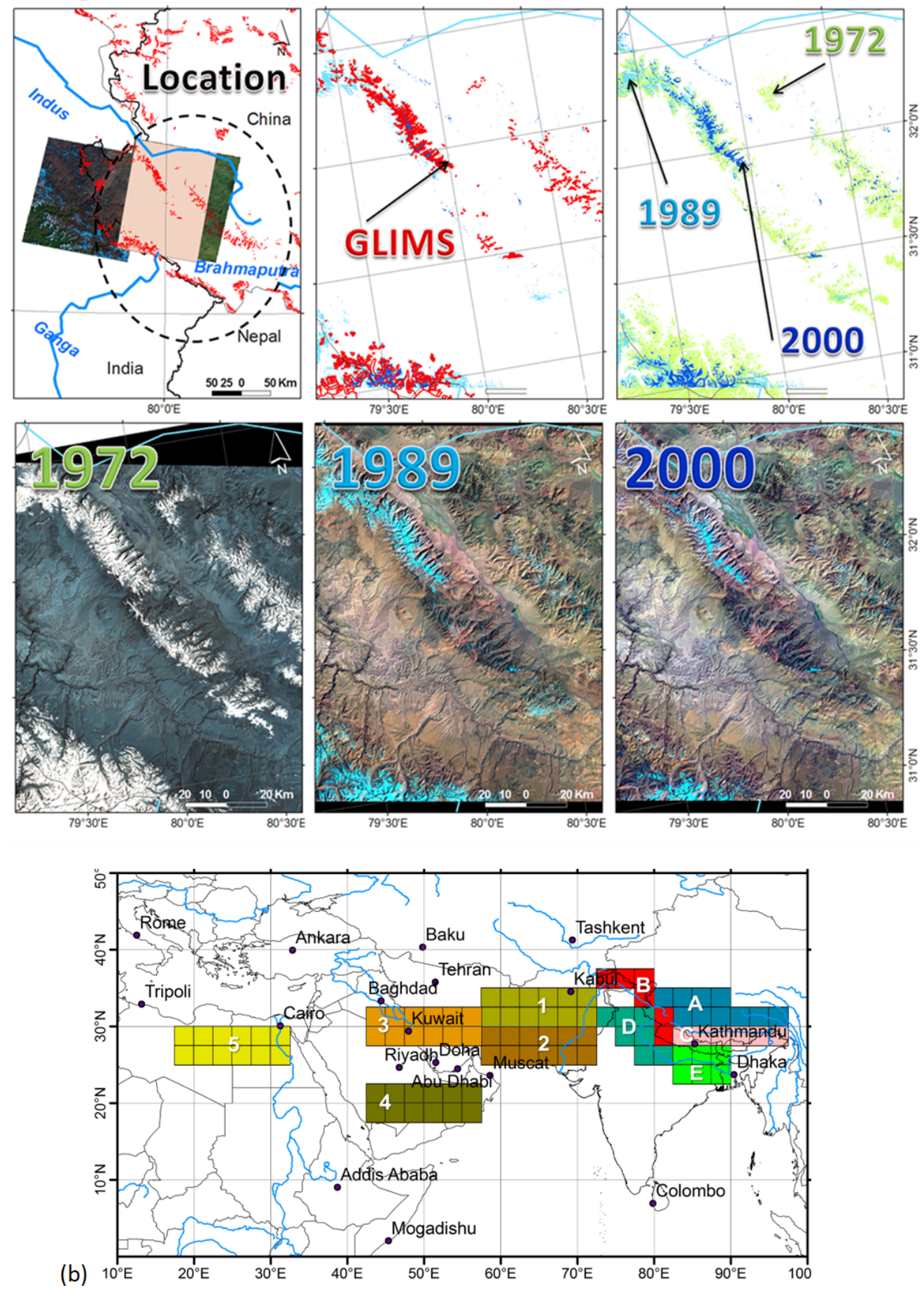

Fig. 1. (a) The upper panel show the major western Himalayan Glaciers area and the point of origin of major rivers of Asia, namely Indus, Ganga and Brahmaputra. The snow cover extent is shown in green (year 1972), light blue (year 1989) and deep blue (year 2000) as measured from Landsat and the Global Land Ice Measurements from Space (GLIMS) database (in red). The lower panel shows the extent of snow-glacier cover during years 1972, 1989 and 2000 over Gangotri glacier region (circled area, top panel). (b) Sub-division of study region into Tibetan region (code A), western Himalayas (code B), eastern Himalayas (code C), western IG plains (code D), eastern IG plains (code E). The major dust source regions of Asia-Africa affecting the IG plains and Himalayas are (1) Afghanistan-Pakistan region, (2) Iran-Pakistan-Thar desert region, (3) Middle East, (4) Arabian region, and (5) Sahara desert. 
The relative weighting function peaks between $0-3 \mathrm{~km}$ from the surface for TLT and 3-7 km for TMT. The TMT channel (MSU2/AMSU5) has a significant (5\% to 15\%) weight in the stratosphere (Mears and Wentz, 2009). This leads to masking of the tropospheric warming due to contributions from the general stratospheric cooling. The trend difference between T850-300 (Fu corrected MSU) and T2 for the tropics is smaller $(0.05 \mathrm{~K}$ per decade, that is $0.15 \mathrm{~K}$ for 30 years) (Fu et al., 2004). Johanson and $\mathrm{Fu}$ (2004) noted that despite these validations, debate continues over the ability of the statistically based global-mean (Fu et al., 2004) retrieval to accurately remove the stratospheric contamination (e.g., R. W. Spencer and J. R. Christy, personal communication, 2005; NRC, 2005; Tett and Thorne, 2004; Fu et al., 2004b). Due to stratospheric influence, that would correspond to $15-20 \%$ increase in our (RSS data v3.2) warming values of 0.90 and $0.78 \mathrm{~K}$ for MAM over Himalayas+IG plains and Himalayas+Tibet+IG plains, respectively. However, we are also providing error bounds that show upper and lower limits of the trend values that would cover such errors due to stratospheric contamination. Fu et al. (2004) observed that this masking effect decreases global TMT trends by $\sim 0.04 \mathrm{~K} /$ decade (1979-2005) based on a weighted combination of TMT and TLS (Temperature Lower Stratosphere) measurements. Various methods like Fu et al. (2004), Fu and Johanson (2004) have been applied to correct for $15 \%$ weight with mixed success rate. The combination approach, used by other researchers to decrease the effect of stratospheric cooling and increase the sensitivity of the MSU channel to the lower troposphere, amplifies noise (Mears et al., 2003). The adjusted temperature trend (between $5^{\circ} \mathrm{S}$ to $20^{\circ} \mathrm{N}$ ) taken from radiosondes was found to be close to that observed from MSU TLT (Sherwood et al., 2008). For channel 2, it was consistent with two analyses (RSS, $p=0.54$, and the University of Maryland, $p=0.32$ ) but not with the University of Alabama dataset ( $p=0.0001$ ) (Sherwood et al., 2008). The RSS MSU data, collocated from 58 radiosonde stations in the tropics $\left(20^{\circ} \mathrm{S}-20^{\circ} \mathrm{N}\right)$ during the period of 1979-2004 show $+0.15^{\circ} \mathrm{K} /$ decade while the UAH processed data show $+0.07^{\circ} \mathrm{K} /$ decade (Christy et al., 2007). The comparison of the RSS-derived tropospheric temperature trend with four different observed estimates of surface temperature changes over the tropical troposphere show consistency with the model results (Santer et al., 2008). Santer et al. (2008) found that the RSS-based (v3.0, T2 and T2LT data) estimates of tropical lapse-rate changes are in better agreement with the satellite datasets developed by the University of Maryland (UMD) and NOAA/NESDIS groups and with basic moist adiabatic lapse-rate theory.

The new product (v3.2) available from RSS, used in this study, is more stable as it incorporates the results from the extensive study of inter-calibration issues, drifts with time, diurnal variation, latitude dependent inter-satellite offsets, and exclusion of spurious datasets between 9 sensors (Mears and Wentz, 2009). The new version 3.2 MSU product is more stable compared to previous products (v3 and 3.1) and are released for multi-decadal study of trends in climate studies. Further, our results presents trends present in the RSS v3.2 dataset which would be beneficial for users or readers to see the range of trends compared to previous results or other datasets.

\subsection{AIRS mid-tropospheric $\mathrm{CO}_{2}$ data}

We have used the monthly dataset, level-3 Carbon Dioxide $\left(\mathrm{CO}_{2}\right)$ in the free troposphere, from AIRS/Aqua (AIRX3C2M). AIRX3C2M is the mid-tropospheric $\mathrm{CO}_{2}$ levels derived from the AIRS and AMSU instruments on board the Aqua satellite. The gridded $\mathrm{CO}_{2}$ data is available at $2.5 \times 2$ degree grid cell size. The AIRS+AMSU $\mathrm{CO}_{2}$ data clearly show not only effects of large-scale surface sources, but also large scale circulations such as the mid-latitude jet streams. The sources, sinks and transport of $\mathrm{CO}_{2}$ in the atmosphere, as observed in AIRS+AMSU data, will help to improve the chemistry-transport models that are used for carbon-budgets (Chahine et al., 2008). The $\mathrm{CO}_{2}$ data would also help to better understand and model the inhomogeneous heating of the earth's atmosphere over the tropics and mid-latitudes as observed from the MSU/AMSU data. The AIRS middle-tropospheric $\mathrm{CO}_{2}$ product and the National Oceanic and Atmospheric Administration Earth System Research Laboratory/Global Monitoring Division (NOAA ESRL/GMD) aircraft $\mathrm{CO}_{2}$ estimates agree to approximately $\pm 0.5 \%$ between \pm 65 degrees latitude (Maddy et al., 2008). We have used the AIRS+AMSU CO $\mathrm{CO}_{2}$ data (20032008) to associate with the periods of warming trend over mid-latitudes as observed from the MSU/AMSU temperature trend.

\subsection{Daily variation of sunlight data}

We have obtained sunlight duration data as daily variation of sunlight (in minutes) for one year. The data were obtained for Delhi, India, located in the western IG plains, from the website http://ptaff.ca/soleil/. We have used the monthly variation of sunlight duration to partially explain the observed seasonal oscillation in the atmospheric temperature trend data.

\section{Long term MSU troposphere temperature trend}

\subsection{TMT (Mid troposphere) temperature trend}

\subsubsection{Dust sink and snow-glacier cover regions}

In general, we observe that the mid-tropospheric temperatures over the major dust sink regions (IG plains) and surrounding snow-cover and glacial areas (Himalayas and Tibetan Plateau) show a statistically significant warming trend for six months (December to May) while a relatively neutral 


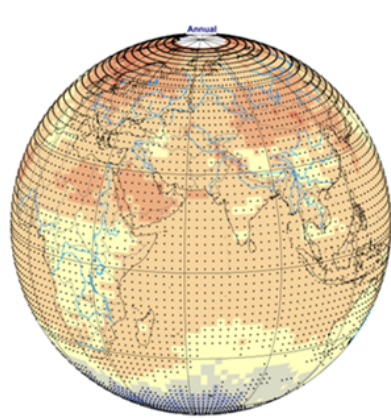

(a)

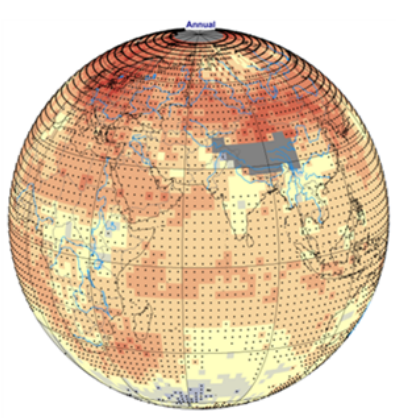

(b)

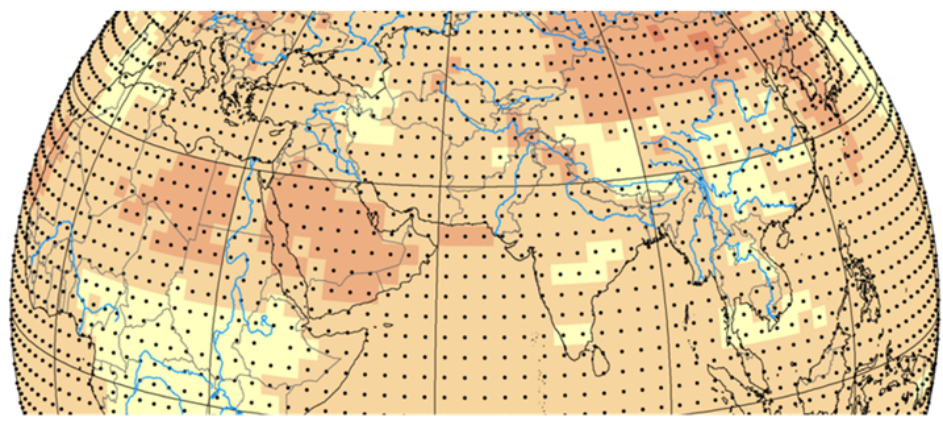

Annual TMT temperature trend (1979-2008)

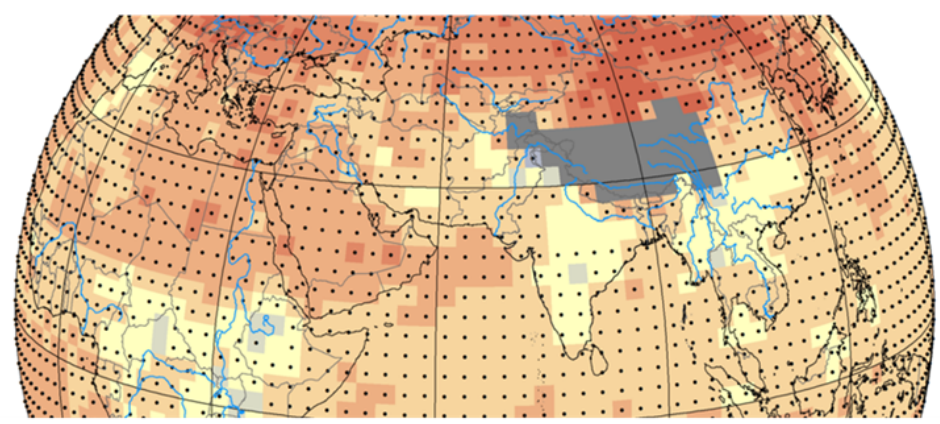

Annual TLT temperature trend (1979-2008)
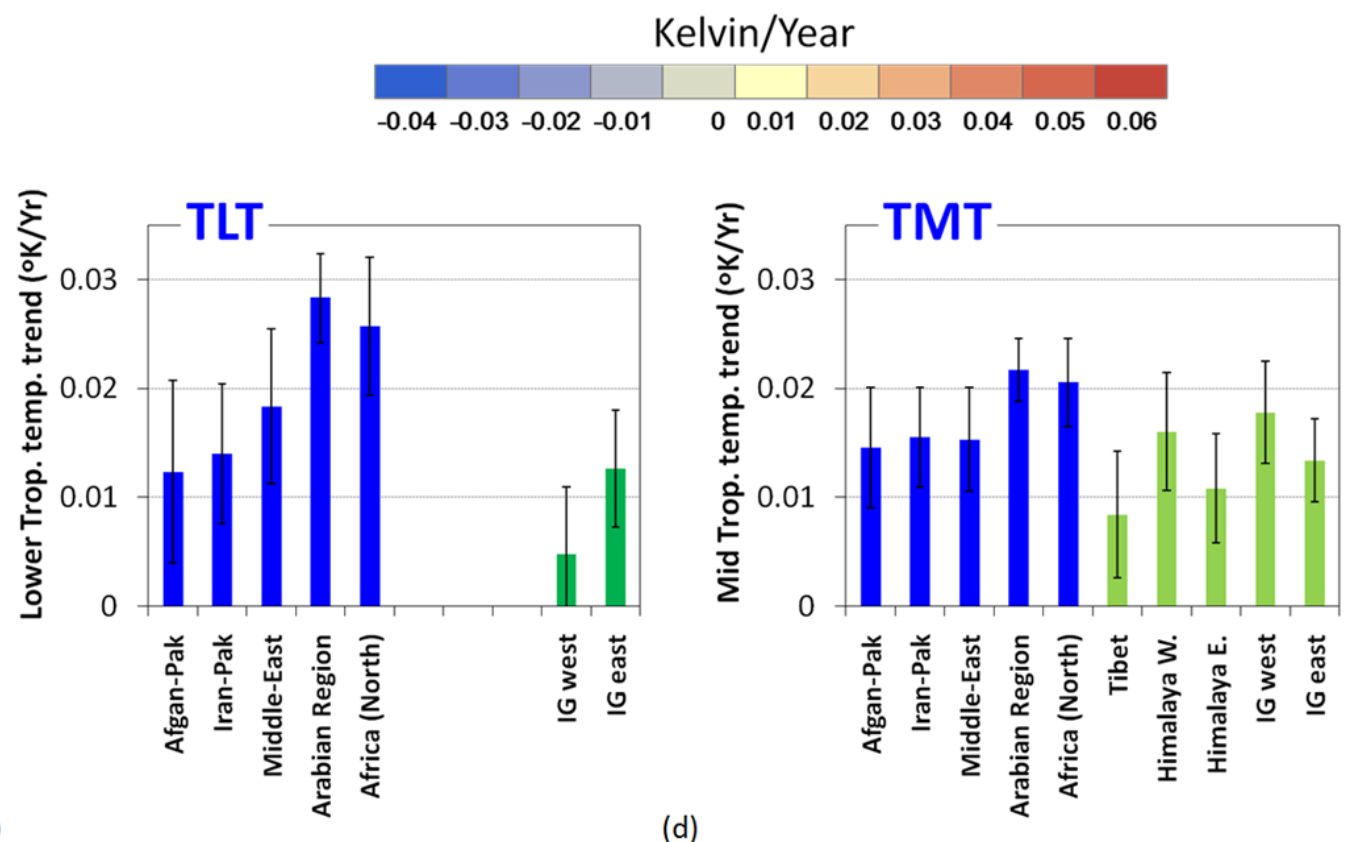

(c)

Fig. 2. The annual linear trend $\left({ }^{\circ}\right.$ Kelvin/year) of brightness temperature based on 30 years (1979-2008) of MSU (a) TMT (mid-troposphere) and (b) TLT (lower troposphere) anomaly data. Mean annual tropospheric temperature trend with standard error $\left({ }^{\circ}\right.$ Kelvin/year) for (c) lower troposphere, and (d) mid-troposphere over different study regions. The black dot at the center of any box (a, b) represent that the calculated linear trend value is statistically significant at alpha 0.05 (95\% CI).

or cooling trend of lesser magnitude (statistically insignificant) from June to November (Figs. 1b, 2a, 3a, b). The mid tropospheric temperature trend from TMT, for each month separately, shows significant mean warming (at $95 \%$ C.I.) of up to $0.051 \pm 0.024(\max 0.068 \pm 0.029)^{\circ} \mathrm{K} /$ year over the Tibetan Plateau, western and eastern Himalayas, and western 
MSU TMT (Middle troposphere)

Linear trend of temperature (1979-2008), 30 years, monthly decomposition
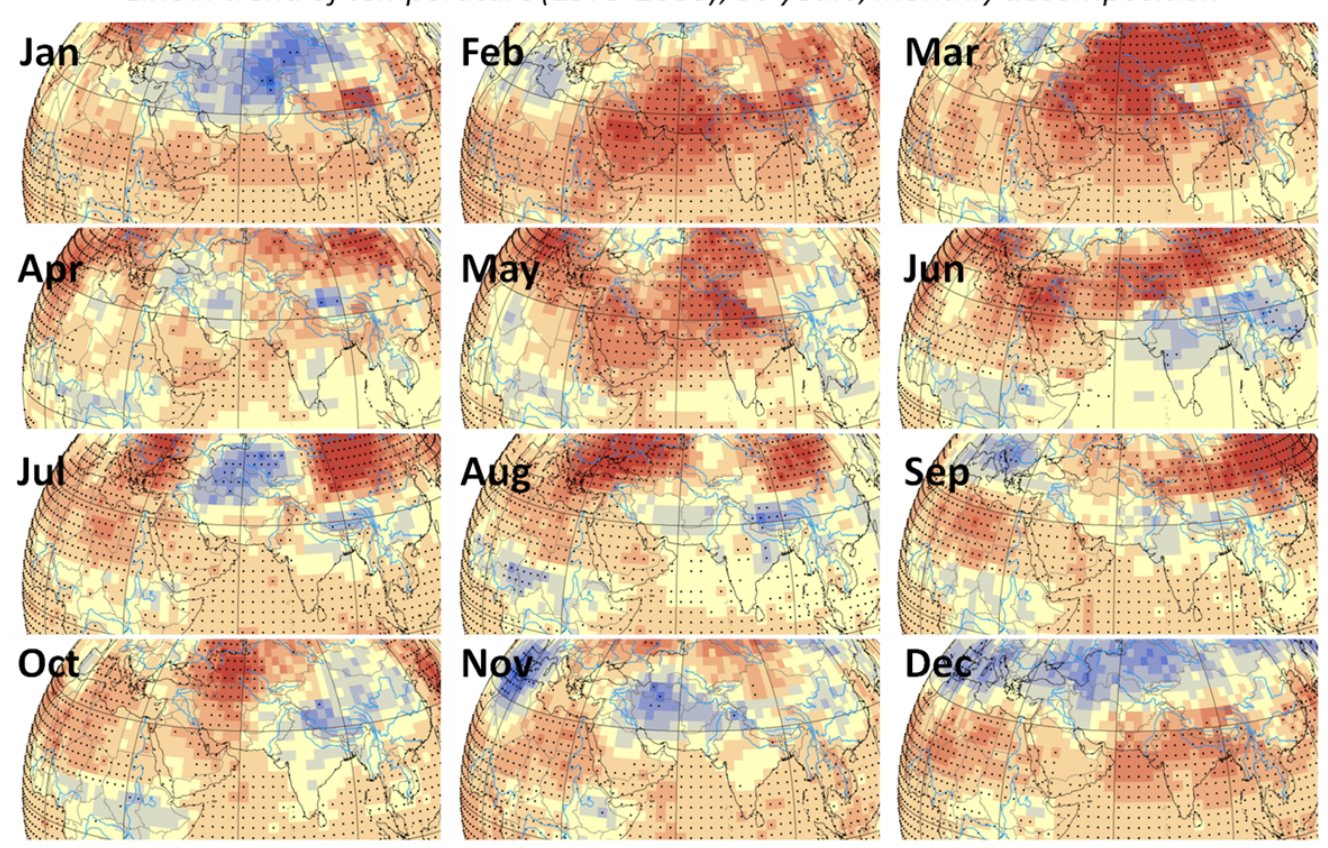

\section{Kelvin/Year}

(a)
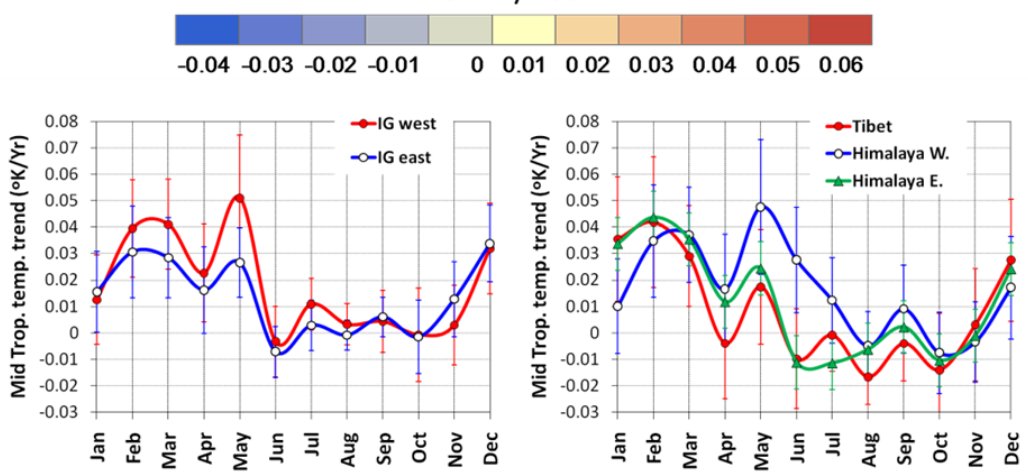

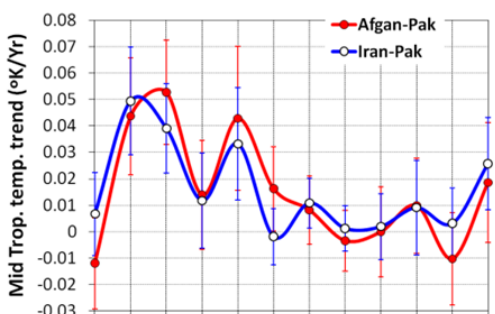

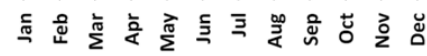

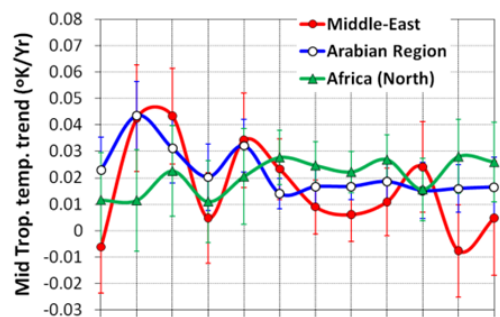

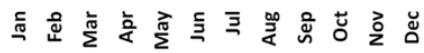

(b)

Fig. 3. The month-to-month linear trend ( ${ }^{\circ}$ Kelvin/year) of brightness temperature based on 30 years (1979-2008) of MSU TMT anomaly data. The month-to-month linear trend is shown over (a) map, and (b) specific study regions (mean trend with standard error) (Fig. 1b). The black dot at the center of any box (a) represent that the calculated linear trend value is statistically significant at alpha 0.05 (95\% CI).

and eastern IG plains (Fig. 3a, b). This amounts to a mean temperature increase of $1.44(\max .2 .04)^{\circ} \mathrm{K}$ over a period of 30 years. The western Himalayas show annual mean
TMT trend of $0.48^{\circ} \mathrm{K}\left(0.016 \pm 0.005^{\circ} \mathrm{K} /\right.$ year $)$ over 1979 2008 which is substantially lower compared to $\sim 1.0^{\circ} \mathrm{K}$ during 1979-2007 by Gautam et al. (2009). Our results show 
that the annual mean TMT trend $\left(0.018 \pm 0.005^{\circ} \mathrm{K} /\right.$ year $)$ is higher over the western IG plains (Fig. 2d) compared to the eastern IG plains $\left(0.013 \pm 0.004^{\circ} \mathrm{K} /\right.$ year $)$. Over the IG plains, the warming trend is prominent and statistically significant $\left(>0.030^{\circ} \mathrm{K} /\right.$ year) during December, February, March and May. This warming trend is particularly greater over the western region compared to the eastern region, during February, March and May (Fig. 3a, b). During the other half of the year (June-November), the relatively neutral (near zero ${ }^{\circ} \mathrm{K} / \mathrm{year}$ ) or cooling (slightly negative, up to $-0.017 \pm 0.010^{\circ} \mathrm{K} /$ year) temperature trend over the sink region is mostly insignificant at 95\% C.I. (Fig. 3a, b). The monthly decomposition of the temperature trend shows that the mean annual warming of $0.008 \pm 0.006^{\circ} \mathrm{K} /$ year over the Tibetan Plateau and $0.016 \pm 0.005^{\circ} \mathrm{K} / \mathrm{year}$ over the Himalayas (Fig. 2c) occurs only over a period of 6 months (December-May) (Fig. 3b). The inequality of the warming trend between the eastern and western regions (Himalaya) is perceptible for individual months when compared to the mean annual trend (Figs. 2c, 3a, b) which is anticipated based on previous studies of the region (He et al., 2003). Similarly, the IG plains also show different warming trends between the eastern and western regions (Fig. 3a, b). The Tibetan Plateau also shows a similar mean warming trend over six consecutive months (December-May) with peak during February $\left(0.042 \pm 0.025^{\circ} \mathrm{K} /\right.$ year $)$.

\subsubsection{Dust source regions}

As with the dust sink regions, the mid-tropospheric temperatures over the major dust source regions show a statistically significant mean warming trend for the same six months (December to May) while a relatively neutral or near zero (range $-0.010 \pm 0.018$ to $0.028 \pm 0.014^{\circ} \mathrm{K} /$ year) trend from June to November (Fig. 3a, b). The calculated linear trend is also insignificant at $95 \%$ CI during the June-November period over the Afghan-Pakistan and Iran-Pakistan regions (Fig. 3a). The exception is the Saharan desert (north Africa) that shows a consistent mean warming trend that varies between $0.011 \pm 0.010$ to $0.028 \pm 0.014^{\circ} \mathrm{K} /$ year, throughout the year (Fig. 3b). However, we see similar oscillations in the warming trends over the six month period, just south of the Saharan Desert (Fig. 3a). The nature of the oscillation of the warming trend from December to May over the Afghan-Pakistan region, located west of the IG plains, is similar to that of the IG plains (Fig. 3b). However, the magnitude of the mean warming trend over the AfghanPakistan and Iran-Pakistan regions is relatively higher (up to $0.049 \pm 0.020,0.053 \pm 0.020,0.043 \pm 0.027^{\circ} \mathrm{K} /$ year during February, March and May, respectively) (Fig. 3b). Similarly, the Middle East and Arabian regions, which are also a major source of dust for the IG plains, shows similar mean warming trends with major peaks in FebruaryMarch (up to $0.044 \pm 0.013$ and $0.043 \pm 0.018^{\circ} \mathrm{K} /$ year), and in May $\left(0.034 \pm 0.018^{\circ} \mathrm{K} /\right.$ year) (Fig. 3b). The mean annual warming trend over the dust source regions varies between $0.015 \pm 0.006$ to $0.022 \pm 0.003^{\circ} \mathrm{K} /$ year (Fig. $2 \mathrm{c}$ ), while individual months (February, March and May) show that the mean warming trend is $2-3$ times more than the annual mean and is concentrated over half of the year (December-May) (Fig. 3b).

The absence of, as well as the statistical insignificance of the warming/cooling trend starting in June and ending in November, is noticeable over both dust source and sink regions. The differential warming over the eastern and western regions, as well as the general warming trend that is spread only over six months (December-May) is discussed in the next section (Sect. 4).

\subsection{TLT (lower troposphere) temperature trend}

\subsubsection{Dust sink regions}

The lower tropospheric region $(0-3 \mathrm{~km})$, where the concentration of dust or aerosols is relatively greater (Ramanathan et al., 2005, 2007), also shows a similar warming trend, with a relatively higher magnitude over six months (DecemberMay) as compared to the mid troposphere (4-7 km) (Fig. 4a). The peaks of the mean warming trend are observed during December (up to $0.032 \pm 0.023^{\circ} \mathrm{K} /$ year) and February (up to $0.032 \pm 0.026^{\circ} \mathrm{K} /$ year) and then gradually decline until May (up to $0.027 \pm 0.028^{\circ} \mathrm{K} /$ year) over the IG plains (Fig. 4b). Though the mean aerosol loading over the IG plains is at its maximum (AOD $>0.7)$ and gradually increases during the summer months, April-May-June (AOD >0.7-0.9) (Prasad and Singh, 2007a; Singh et al., 2004), a sharp decline is observed in the temperature trend from positive (April-May) to negative (June) (Figs. 3, 4). June, though marked by higher aerosol concentrations, is also a month of contrasting transition over the mid troposphere (both dust source and sink regions) (Figs. 3b, 4b). This implies that the mean warming trend during December-May is also strongly modulated by controlling factors other than aerosols. Over the western IG plains, a significant cooling trend (up to $-0.040 \pm 0.016^{\circ} \mathrm{K} /$ year) is also observed during the JuneNovember period. The contrast between the western and eastern IG plains, as seen in the map of mean TLT temperature trends for individual months (Fig. 4a), is notable during both the warming and cooling trend periods. The western IG plains, which also show higher aerosol loading as compared to the eastern IG plains, show a higher magnitude in both the warming and cooling trends (Figs. 3a, b, 4a, b). In general, the warming and cooling maxima are found more in higher aerosol loading regions over the IG plains.

\subsubsection{Dust source regions}

Like the mid tropospheric temperature trend, the lower tropospheric temperature trend shows similar variability in its monthly variation but with a higher magnitude 
MSU TLT (lower troposphere)
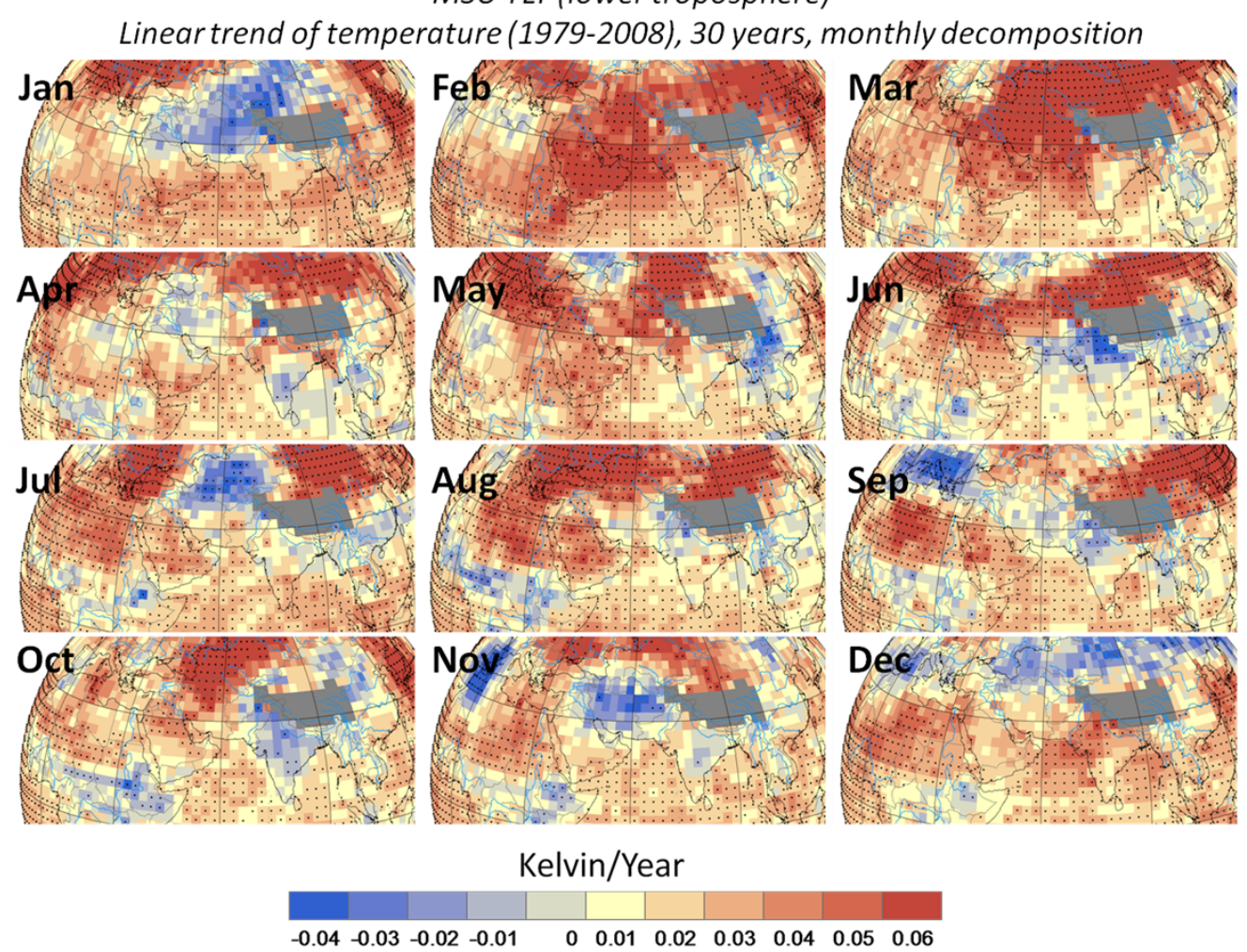

(a)

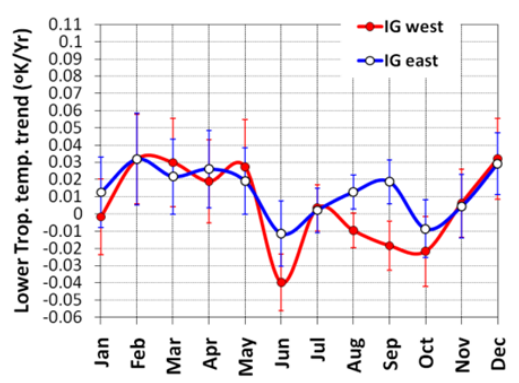

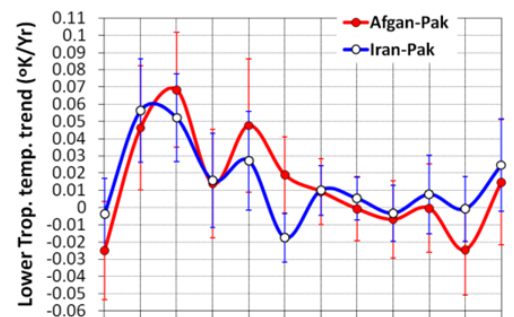

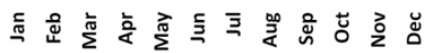

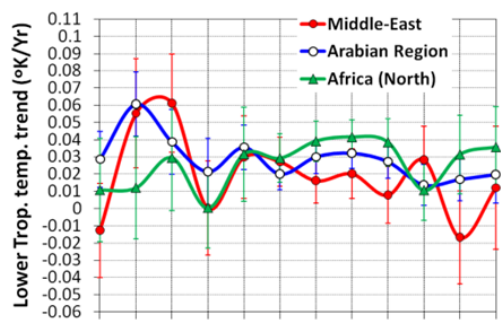

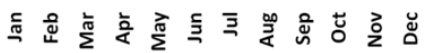

(b)

Fig. 4. The month-to-month linear trend $\left({ }^{\circ}\right.$ Kelvin/year) of brightness temperature based on 30 years (1979-2008) of MSU TLT anomaly data. The month-to-month linear trend is shown over (a) map, and (b) specific study regions (mean trend with standard error) (Fig. 1b). The black dot at the center of any box (a) represent that the calculated linear trend value is statistically significant at alpha 0.05 (95\% CI).

(Figs. 3b, 4b). During the six month mean warming trend (December-May), the maxima of positive temperature trends occur during February $\left(0.056 \pm 0.030^{\circ} \mathrm{K} /\right.$ year $)$, March $\left(0.068 \pm 0.033^{\circ} \mathrm{K} /\right.$ year $)$ and May $\left(0.048 \pm 0.039^{\circ} \mathrm{K} /\right.$ year $)$ over the Afghan-Pakistan and Iran-Pakistan regions (Fig. 4b). Similar mean warming trend maxima occur during February $\left(0.055 \pm 0.032^{\circ} \mathrm{K} / \mathrm{year}\right)$ and March $\left(0.061 \pm 0.028^{\circ} \mathrm{K} /\right.$ year $)$ over the Middle-East region. The Sahara desert (Africa) 
region does not show a contrasting warming trend that is limited to six months over other regions (Fig. 4b). However, the northern African region shows a similar warming trend that is limited to December-May. The regions that experience a cooling trend over Africa, between June and November, are mostly observed to be statistically insignificant (Fig. 4a). In general, the major dust producing source regions, which are mostly arid and desert-like regions in Africa and Asia, largely follow the increasing warming trend that is spread over six months (December-May).

\section{Discussion}

The western Himalayan region shows an increase in lower and mid-tropospheric temperatures in the long-term record available from MSU (1978-2008). However, the monthwise decomposition of the mean annual warming trend $\left(0.016 \pm 0.005^{\circ} \mathrm{K} /\right.$ year $)$ shows that the statistically significant and enhanced warming occurs mostly over a period of only six months (December to May) (Figs. 2a, d, 3a, d). Over the Indian subcontinent, the period from December to May, is comprised of a cold season (winter, November-February), a short spring (March) and a summer season, (April-June). Over the western Himalayas and IG plains region, in any given year, the coldest months are December and January while the warmest months are April-May-June. The enhanced warming over major glacial regions of the western Himalayas during phases of snow accumulation and melting implies an accelerated snow melt in the region. The typical six-month warming trend shows a 2-3 times higher magnitude over individual months when compared to the mean annual trend (Figs. 2c, d, 3b, 4b). The maxima of the mean monthly warming TMT trend is around 0.48 and $0.51^{\circ} \mathrm{K} /$ decade (or $0.048 \pm 0.026$ and $0.051 \pm 0.024^{\circ} \mathrm{K} /$ year) over the Himalayas and IG plains, respectively. The difference between the western and eastern Himalayas and IG plains is also conspicuous, which can partly be explained by the difference in the level of anthropogenic pollution and aerosol loading, which is at its maximum during the winter and summer months, between the western and eastern parts of the Indian sub-continent (Prasad et al., 2006a; Prasad and Singh, 2007a; Singh, 2004). The monthly warming trend shows matching oscillations over the dust source regions (Afghan-Pakistan, Iran-Pakistan, Middle East, Arabia) (Figs. 3b, 4b). The warming of the mid and lower troposphere in mid-latitude areas is perceptible all across Africa, west Asia (middle east region) and over the Indian subcontinent (Figs. 2a,b, 3a, 4a). They follow the conspicuous sixmonth enhanced warming trend.

\subsection{Role of aerosols, and greenhouse gases}

The six-month warming trend from MSU data is not just related to higher aerosol (dust and pollution) loading in the atmosphere. The seasonal and monthly variability of atmospheric $\mathrm{CO}_{2}$ also follows the similar six-month increase (from December-May) and the following six-month gradual decrease (Fig. 5a). The greenhouse gases, such as $\mathrm{CO}_{2}$ and water vapor, are spread more evenly in the atmosphere compared to aerosols which show hot spot regions or belts across the globe. Water vapor, as a greenhouse gas, has more influence in the lower troposphere, as the concentration is higher there.

Aerosols are more unevenly spread spatially and therefore affect particular regions more than others, which are more pronounced over certain hot spot belts (Ramanathan et al., 2005, 2007). These belts are comprised of the major arid and desert regions, dust source and sink regions in Asia and Africa (Fig. 1b), and regions affected by anthropogenic pollution. The influence of aerosols and anthropogenic pollution on atmospheric temperature (lower and middle troposphere) is noticeable over the western and eastern IG plains that show a large gradient in the magnitude of the warming trends from west to east (Figs. 3a, 4a).

Though the aerosol loading is higher during winter (November-February) and highest during Summer (AprilJune) over the IG plains, the composition and optical properties of aerosol vary (Prasad et al., 2006a, b; Prasad and Singh, 2007a), and the anticipated effects are clearly noticeable on TMT and TLT trends with some exceptions (Fig. 5c). The winter season comprises of mostly fine particles with high concentrations of black carbon which are absorbing in nature and are efficient in trapping heat. We see that the effect of fine aerosols (and black carbon) on the lower troposphere during December and February. However, during summer time, the coarser mineral dust aerosols which are scattering in nature dominate the total aerosol concentration. The large scattering effect leads to relative cooling of the lower atmosphere that can explain relatively warmer trend from TMT data.

Though June, like May, is one of the warmest months in the IG plains and has one of the highest concentrations of aerosols in the atmosphere (Prasad et al., 2006a; Prasad and Singh, 2007a), conspicuous differences can be seen in the observed monthly warming trend between those two months (Figs. 3b, 4b). During end of the summer season (June), we observe maximum cooling effect in the TLT trend that is also statistically significant (at 95\% CI). The maxima of mean cooling trend (TLT and TMT) over the IG plains occur during June that is conspicuously different from other summer months (April-June) with high mineral dust loadings. The aerosols cannot explain exceptional cooling trend observed during June and this aspect needs to be investigated.

Over the IG plains, the monsoon rainfall starts in July, which not only washes out the aerosols in the atmosphere (low aerosol loading), but also increases water vapor content in the atmosphere (Prasad and Singh, 2009; Prasad et al., 2007). The aerosol concentration is lowest over IG plains during July-August due to heavy monsoon rainfall and that 

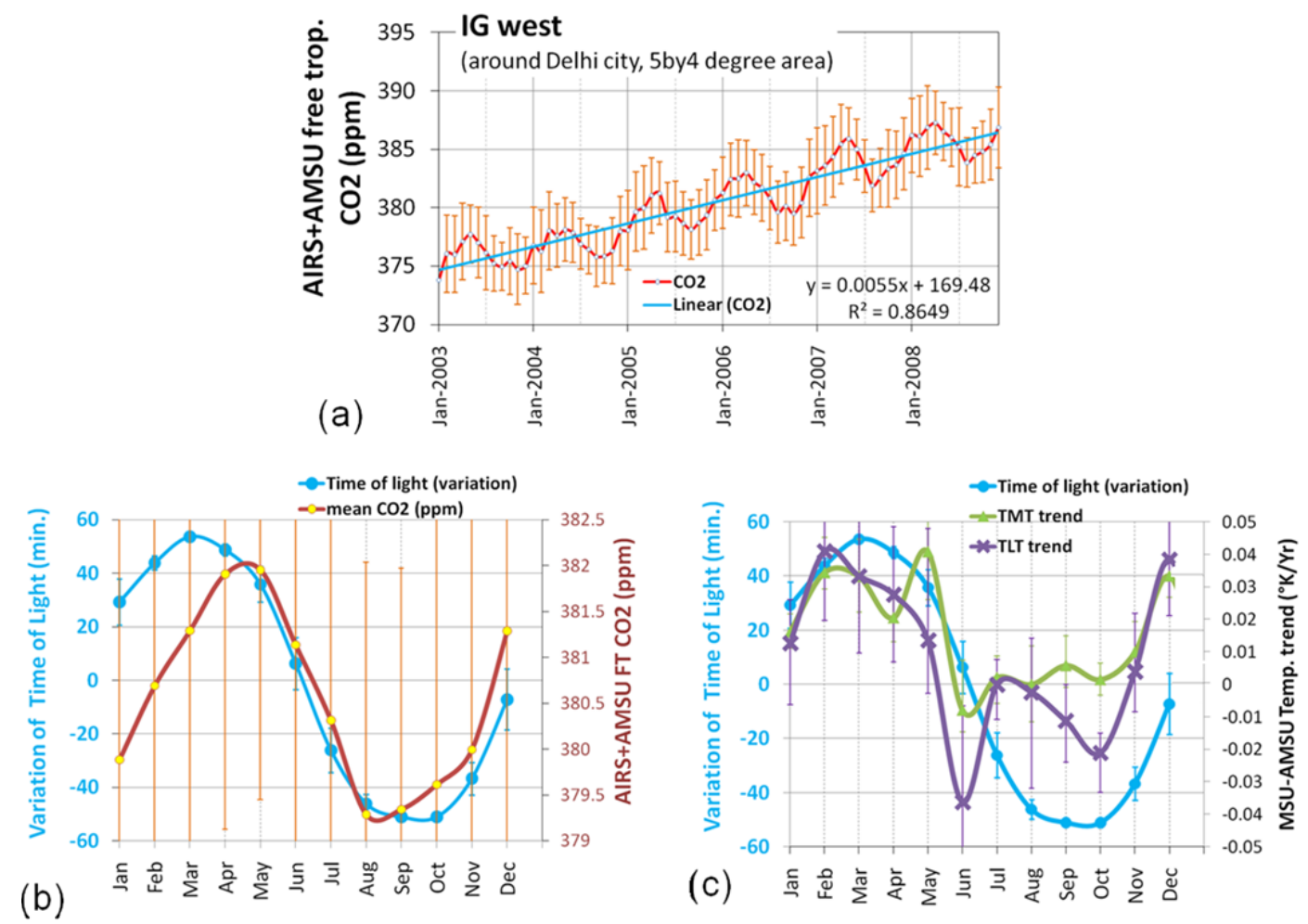

Fig. 5. (a) The increasing trend of free troposphere $\mathrm{CO}_{2}$ (AIRS+AMSU) over the western IG plains. The seasonal oscillation of $\mathrm{CO}_{2}$ is prominent. (b) The mean monthly $\mathrm{CO}_{2}$ show seasonal sinuous pattern of variation which matches well with the observed available sunlight. (c) The six months of warming trend (TMT and TLT) are observed to be during period when the available sunlight duration and $\mathrm{CO}_{2}$ is on the high (positive) side of the seasonal oscillation.

leads to negligible cooling or heating trend (TMT) (Fig. 5c). Though the aerosol concentration is lowest over the eastern IG plains compared to western IG plains during monsoon season (July-September), the eastern IG plains show a warming trend especially during August and September (Fig. 4b). The lower troposphere over the eastern IG plains show much higher moisture content compared to the western IG plains (Prasad et al., 2007) that can potentially explain the observed difference between western and eastern IG plains during monsoon season (Fig. 4b). Further study is required to quantify the effect of moisture on TLT trends especially during monsoon season (wet months) compared to dry months. However, the observed trend over the IG plains is not statistically significant over the entire area during monsoon months (Figs. 3a, 4a).

\subsection{Role of solar cycle (solar day length)}

The daily variation of sunlight is linked to the Earth's tilt and elliptical rotation around the Sun and has a sinusoidal wave pattern. The monthly variation of the solar day length for one year (year 2009) is shown over Delhi, India in the western IG plains (Fig. 5b, c).

The enhanced warming trend observed in MSU data occurs from December to May, which is the winter and spring seasons over the northern mid-latitudes. April, May, and June are the warmest (pre-monsoon) months while November, December, January, and February are winter months over the IG plains with a short spring during March. The enhanced warming trend over the western Himalayas and IG plains (Figs. 3b, 4b) during this period may imply a shorter snowfall period during winter and accelerated glacial melting during April and May. The significant tropospheric warming trend $\left(0.6^{\circ} \mathrm{K} /\right.$ decade for $1979-2005$, $\left.120^{\circ} \mathrm{W}-180^{\circ} \mathrm{W}\right)$ prevails over Antarctic during winters and springs (Johanson and $\mathrm{Fu}, 2007$ ), which is opposite to that observed over the Northern Hemisphere in this study and consistent with the present results.

The monthly atmospheric temperature trend analysis (lower and middle troposphere) shows effects of the seasonal temperature modulations by aerosols and greenhouse gases such as $\mathrm{CO}_{2}$ and water vapor. It is apparent that the sun also plays a larger role in month-to-month variation of the tropospheric warming trend. This also partly explains the sixmonth warming trend, when the solar day length is higher during January-May over the northern mid-latitude region. The sun, aerosols, and greenhouse gases (such as $\mathrm{CO}_{2}$ and water vapor) show synergy with the month-to-month warming trend of the lower and middle troposphere over the mid 
latitudes of Asia and Africa (Fig. 5b, c) that need further study. The quantitative feedback relationship between different variables may explain the spatial and seasonal variation of the warming trend from MSU data.

\section{Conclusions}

The lower (TLT) and mid (TMT) tropopsheric trends from MSU (1979-2008, 30 years) show enhanced warming of the northern mid-latitudes, but are mainly limited to a period of six months (December-May). The warming of midtroposphere during March-April-May (MAM) period is observed to be $0.90^{\circ} \mathrm{K}$ and $0.78^{\circ} \mathrm{K}$ (or 0.030 and $0.027^{\circ} \mathrm{K} /$ year) over Himalayas+IG plains and Himalayas+Tibet $+\mathrm{IG}$ plains, respectively compared to $2.7^{\circ} \mathrm{K}$ (or $0.0931^{\circ} \mathrm{K} /$ year) by Gautam et al. (2009) during last 3 decades. Similarly, warming during December-January-February (DJF, 1979-2008) is found to be $0.86^{\circ} \mathrm{K}$ and $0.82^{\circ} \mathrm{K}$ over Himalayas+IG plains and Himalayas+Tibet+IG plains, respectively. The observed warming trend is statistically significant (at $95 \% \mathrm{CI}$ ). The major dust source and sink regions of Asia show similar month to month oscillations in the warming trends. The change of the warming (positive) trend to near zero or negative from June to November is also prominent. Most of the observed neutral or cooling trends over the study region during June-November are insignificant. Though both May and June are the hottest months along with the highest aerosol loading over the western IG plains, the contrasting change in the MSU trends (both TLT and TMT) can be partially attributed to the mixed influence and feedback from other controlling factors such as sunlight duration, $\mathrm{CO}_{2}$ oscillation, and increase in water vapor content. Sunlight duration and $\mathrm{CO}_{2}$ over the study region (latitude dependent) also follow a sinusoidal wave pattern over a year with highs during December to May and lows during June to November. The seasonal oscillation of the sunlight duration, $\mathrm{CO}_{2}$ in the atmosphere, water vapor (wet and dry months) and aerosol distribution may partially explain the six-month trend of enhanced tropospheric warming. The higher magnitude (2-3 times more) of tropospheric warming, especially during April-May, would mean accelerated melting of the Himalayan glaciers. The MSU trend found over the Himalayas, Tibetan Plateau and surrounding regions support the negative effect of global warming on the snow cover and glacial area since 1979. Melting of the cryosphere regions in the Himalayas is likely to accelerate due to warming up of the atmosphere during December-May. This would have profound implications for regional and global climate change and a source of major socio-economic concern.

Acknowledgements. MSU data are produced by Remote Sensing Systems and sponsored by the NOAA Climate and Global Change Program. Data are available at www.remss.com. We are also thankful to the AIRS science team at NASA/JPL (http://airs.jpl.nasa.gov) for providing AIRS+AMSU free troposphere $\mathrm{CO}_{2}$ data. We are grateful to Emmanuel Smith for his help in improving the original version of the manuscript. We are thankful to the Reviewer's for their constructive suggestions. This work is partially funded by the USDA grant 58-3148-7-044, as well as through NASA GEC-hri grant NNX06AF30G and NNX09AH20G and support from technical officers Don Anderson and Lucia Tsaoussi.

Topical Editor F. D'Andrea thanks four anonymous referees for their help in evaluating this paper.

\section{References}

Arora, M., Goel, N. K., and Singh, P.: Evaluation of temperature trends over India, Hydrol. Sci. J., 50(1), 81-93, 2005.

Benn, D. I. and Owen, L. A.: The role of the Indian summer monsoon and the mid-latitude westerlies in Himalayan glaciation: review and speculative discussion, J. Geological Soc., 155, 353363, Part 2, 1998.

Berthier, E.: Dynamics and mass balance of mountain glaciers (Alps, Iceland, Himalaya). Contribution of satellite imagery, Houille Blanche-Revue Internationale de L'eau, 2, 116-121, 2007.

Berthier, E., Arnaud, Y., Kumar, R., Ahmad, S., Wagnon, P., and Chevallier, P.: Remote sensing estimates of glacier mass balances in the Himachal Pradesh (Western Himalaya, India), Rem. Sens. Environ., 108(3), 327-338, 2007.

Chahine, M. T., Chen, L., Dimotakis, P., Jiang, X., Li, Q., Olsen, E. T., Pagano, T., Randerson, J., and Yung, Y. L.: Satellite remote sounding of mid-tropospheric CO2, Geophys. Res. Lett., 35, L17807, doi:10.1029/2008GL035022, 2008.

Christy, J. R., Norris, W. B., Spencer, R. W., and Hnilo, J. J.: Tropospheric temperature change since 1979 from tropical radiosonde and satellite measurements, J. Geophys. Res.-Atmos., 112(D6), D06102, doi:10.1029/2005JD006881, 2007.

Christy, J. R., Spencer, R. W., Norris, W. B., Braswell, W. D., and Parker, D. E.: Error Estimates of Version 5.0 of MSU-AMSU Bulk Atmospheric Temperatures, J. Atmos. Oceanic Technol., 20, 613-629, 2003.

Christy, J. R., Spencer, R. W., and Braswell, W. D.: MSU Tropospheric Temperatures: Dataset Construction and Radiosonde Comparisons, J. Atmos. Oceanic Technol., 17, 1153-1170, 2000.

Dobhal, D. P. and Kumar, S.: Inventory of glacier basins in Himachal Himalaya, J. Geological Soc. India, 48(6), 671-681, 1996.

Duan, K. Q., Thompson, L. G., Yao, T., Davis, M. E., and Mosley-Thompson, E.: A 1000 year history of atmospheric sulfate concentrations in southern Asia as recorded by a Himalayan ice core, Geophys. Res. Lett., 34(1), L01810, doi:10.1029/2006GL027456, 2007.

Fu, Q., Johanson, C. M., Warren, S. G., and Seidel, D. J.: Contribution of Stratospheric Cooling to Satellite-Inferred Tropospheric Temperature Trends, Nature, 429, 55-58, 2004.

Gautam, R., Hsu, N. C., Lau, K.-M., Tsay, S.-C., and Kafatos, M.: Enhanced pre-monsoon warming over the Himalayan-Gangetic region from 1979 to 2007, Geophys. Res. Lett., 36, L07704, doi:10.1029/2009GL037641, 2009.

Grody, N. C., Vinnikov, K. Y., Goldberg, M. D., Sullivan, J. T., and Tarpley, J. D.: Calibration of Multi-Satellite Observations for Climatic Studies: Microwave Sounding Unit (MSU), J. Geophys. Res., 109, D24104, doi:10.1029/2004JD005079, 2004. 
He, Y. Q., Zhang, Z. L., Theakstone, W. H., Chen, T., Yao, T. D., and Pang, H. X.: Changing features of the climate and glaciers in China's monsoonal temperate glacier region, J. Geophys. Res.Atmos., 108(D17), 4530, doi:10.1029/2002JD003365, 2003.

Jain, S. K.: Impact of retreat of Gangotri glacier on the flow of Ganga River, Current Sci., 95(8), 1012-1014, 2008.

Jiawen, R., Zhefan, J., Jianchen, P., and Xiang, Q.: Glacier variations and climate change in the central Himalaya over the past few decades, Ann. Glaciol., 43(1), 218-222, 2006.

Johanson, C. M. and Fu, Q.: Antarctic atmospheric temperature trend patterns from satellite observations, Geophys. Res. Lett., 34(12), L12703, doi:10.1029/2006GL029108, 2007.

Kang, S. C., Wake, C. P., Qin, D. H., Mayewski, P. A., and Yao, T. D.: Monsoon and dust signals recorded in Dasuopu glacier, Tibetan Plateau, J. Glaciol., 46(153), 222-226, 2000.

Kang, S. C., Qin, D., Mayewski, P. A., Xie, S. C., and Duan, K. Q.: Evidence of the Kuwaiti oil fires in the Dasuopu glacier ice core, central Himalaya, J. Glaciol., 47(158), 519-520, 2001.

Kayetha, V. K., Senthilkumar, J., Prasad, A. K., et al.: Effect of dust storm on ocean color and snow parameters, Photonirvachak - J. Ind. Soc. Rem. Sens., 35(1), 1-9, 2007.

Kehrwald, N. M., Thompson, L. G., Tandong, Y., MosleyThompson, E., Schotterer, U., Alfimov, V., Beer, J., Eikenberg, J., and Davis, M. E.: Mass loss on Himalayan glacier endangers water resources, Geophys. Res. Lett., 35, L22503, doi:10.1029/2008GL035556, 2008.

Krishna, A. P.: Snow and glacier cover assessment in the high mountains of Sikkim Himalaya, Hydrol. Processes, 19(12), 2375-2383, 2005.

Kulkarni, A. V. and Bahuguna, I. M.: Glacial retreat in the Baspa basin, himalayas, monitored with satellite stereo data, J. Glaciol., 48, 171-172, 2002.

Kulkarni, A. V. and Alex, S.: Estimation of recent glacial variations in Baspa basin using remote sensing techniques, J. Indian Soc. Remote Sensing, 31, 81-90, 2003.

Kulkarni, A. V., Rathore, B. P., Mahajan, S., and Mathur, P.: Alarming retreat of Parbati Glacier, Beas basin, Himachal Pradesh, Curr. Sci., 88, 1844-1850, 2005.

Kulkarni, A. V., Bahuguna, I. M., Rathore, B. P., et al.: Glacial retreat in Himalaya using Indian Remote Sensing satellite data, Current Sci., 92(1), 69-74, 2007.

Kulkarni, A. V., Mathur, P., Rathore, B. P., Alex, S., Thakur, N., and Kumar, M.: Effect of global warming on snow ablation pattern in the Himalayas, Curr. Sci., 83, 120-123, 2002.

Lau, K.-M. and Kim, K.-M.: Observational relationships between aerosol and Asian monsoon rainfall, and circulation, Geophys. Res. Lett., 33, L21810, doi:10.1029/2006GL027546, 2006.

Lau, K. M., Kim, M. K., and Kim, K. M.: Asian monsoon anomalies induced by aerosol direct effects, Clim. Dynam., 26, 855864, doi:10.1007/s00382-006-0114-z, 2006.

Lee, K., Do, H. S., Hou, S. G., Hong, S. M., Qin, X., Ren, J. W., Liu, Y. P., Rosman, K. J. R., Barbante, C., and Boutron, C. F.: Atmospheric pollution for trace elements in the remote highaltitude atmosphere in central Asia as recorded in snow from Mt. Qomolangma (Everest) of the Himalayas, Sci. Total Environ., 404(1), 171-181, 2008.

Li, X., Cheng, G. D., Jin, H. J., et al.: Cryospheric change in China, Global Planet. Change, 62(3-4), 210-218, 2008.

Liu, X. and Chen, B.: Climatic warming in the Tibetan Plateau dur- ing recent decades, Int. J. Climatol., 20, 1729-1742, 2000.

Lozan, J. L., Grabl, H., and Hupfer, P. (Eds):, Summary: Warning signals from climate, in: Climate of 21st Century: Changes and Risks, Wissenschaftliche Auswertungen, Berlin, Germany, pp. 400-408, 2001.

Maddy, E. S., Barnet, C. D., Goldberg, M., Sweeney, C., and Liu, X.: CO2 retrievals from the Atmospheric Infrared Sounder: Methodology and Validation, J. Geophys. Res.-Atmos., 113(D11), D11105, doi:10.1029/2007JD009402, 2008.

Mears, C. A., Schabel, M., and Wentz, F. J.: A reanalysis of the MSU Channel 2 Tropospheric Temperature Record, J. Climate, 16, 3650-3664, 2003.

Mears, C. and Wentz, F.: Construction of the RSS V3.2 LowerTropospheric Temperature Dataset from the MSU and AMSU Microwave Sounders, J. Atmos. Oceanic Technol., 26(8), 14931509, doi:10.1175/2009JTECHA1237.1, 2009.

Mears, C. A. and Wentz, F. J.: The Effect of Drifting Measurement Time on Satellite-Derived Lower Tropospheric Temperature, Science, published online 11 August 2005, doi:10.1126/science.1114772, 2008.

Mears, C. A., Schabel, M., Wentz, F. J., Santer, B. D., and Govindasamy, B.: Correcting the MSU Middle Tropospheric Temperature for Diurnal Drifts, Proceedings of the International Geophysics and Remote Sensing Symposium, Volume III, pp. 18391841, 2002.

Oerlemans, J.: Extracting climate signals from 169 glacier records, Science, 308, 675-677, 2005.

Ose, T.: The comparison of the simulated response to the regional snow mass anomalies over Tibet, Eastern Europe and Siberia, J. Meteorol. Soc. Jpn., 74, 845-866, 1996.

Prabhakara, C., Iacovazzi Jr., R., Yoo, J.-M., and Dalu, G.: Global warming: Estimation from satellite observations, Geophys. Res. Lett., 27(21), 3517-3520, 2000.

Prasad, A. K. and Singh, R. P.: Validation of MODIS Terra, AIRS, NCEP/DOE AMIP-II Reanalysis-2, and AERONET Sun photometer derived integrated precipitable water vapor using ground-based GPS receivers over India, J. Geophys. Res., 114, D05107, doi:10.1029/2008JD011230, 2009.

Prasad, A. K. and Singh, R. P.: Changes in aerosol parameters during major dust storm events (2001-2005) over the Indo-Gangetic basin using AERONET and MODIS data, J. Geophys. Res., 112(D9), D09208, doi:10.1029/2006JD007778, 2007 a.

Prasad, A. K. and Singh, R. P.: Changes in Himalayan Snow and Glacier Cover Between 1972 and 2000, Eos Trans. AGU, 88(33), 326, 2007b.

Prasad, A. K., Singh, R. P., and Singh, A.: Seasonal climatology of aerosol optical depth over Indian subcontinent: trend and departures in recent years, Int. J. Rem. Sens., 27(12), 2323-2329, doi:10.1080/01431160500043665, 2006a.

Prasad, A. K., Singh, R. P., and Kafatos, M.: Influence of coal based thermal power plants on aerosol optical properties in the Indo-Gangetic basin, Geophys. Res. Lett., 33, L05805, doi:10.1029/2005GL023801, 2006b.

Prasad, A. K., Singh, R. P., Singh, S., and Nanda, D. S.: GPS and Satellite Meteorology for Understanding monsoon dynamics over the Indian sub-continent, IAHS Red Book Series, 313, 33-39, 2007.

Qin, D. H., Mayewski, P. A., Kang, S. C., et al.: Evidence for recent climate change from ice cores in the central Himalaya, Ann. 
Glaciol., 31, 153-158, 2000.

Raina, V. K. and Sangewar, C.: Siachen glacier of Karakorum Mountains, Ladakh its secular retreat, J. Geol. Soc. India, 70, 11-16, 2007.

Ramanathan, V., Chung, C., Kim, D., Betge, T., Buja, L., Kiehl, J. T., Washington, W. M., Fu, Q., Sikka, D. R., and Wild, M.: Atmospheric brown clouds: Impacts on South Asian climate and hydrological cycle, Proc. Natl. Acad. Sci. USA, 102, 5326-5333, doi:10.1073/pnas.0500656102, 2005.

Ramanathan, V., Ramana, M. V., Roberts, G., Kim, D., Corrigan, C. E., Chung, C. E., and Winker, D.: Warming trends in Asia amplified by brown cloud solar absorption, Nature, 448, 575578, doi:10.1038/nature06019, 2007.

Rees, H. G. and Collins, D. N.: Regional differences in response of flow in glacier-fed Himalayan rivers to climatic warming, Hydrol. Processes, 20(10), 2157-2169, 2006.

Rikiishi, K. and Nakasato, H.: Height dependence of the tendency for reduction in seasonal snow cover in the Himalaya and the Tibetan Plateau region, Ann. Glaciol., 43(1), 369-377, doi:10.3189/172756406781811989, 2006.

Santer, B. D., Thorne, P. W., Haimberger, L., Taylor, K. E., Wigley, T. M. L., Lanzante, J. R., Solomon, S., Free, M., Gleckler, P. J., Jones, P. D., Karl, T. R., Klein, S. A., Mears, C., Nychka, D., Schmidt, G. A., Sherwood, S. C., and Wentz, F. J.: Consistency of modelled and observed temperature trends in the tropical troposphere, Int. J. Climatol., 28, 1703-1722, 2008.

Shekhar, M. S. and Dash, S. K.: Effect of Tibetan spring snow on the Indian summer monsoon circulation and associated rainfall, Current Sci., 88(11), 1840-1844, 2005.

Sherwood, S. C., Meyer, C. L., Allen, R. J., and Titchner, H. A.: Robust tropospheric warming revealed by iteratively homogenized radiosonde data, J. Climate, early online release, doi:10.1175/2008JCLI2320.1, 2008.
Singh, R. P., Dey, S., Tripathi, S. N., Tare, V., and Holben, B.: Variability of aerosol parameters over Kanpur, northern India, J. Geophys. Res., 109, D23206, doi:10.1029/2004JD004966, 2004.

Shrestha, A. B., Wake, C. P., Mayewski, P. A., et al.: Maximum temperature trends in the Himalaya and its vicinity: An analysis based on temperature records from Nepal for the period 197194, J. Climate , 12(9), 2775-2786, 1999.

Upadhyay, R.: The melting of the Siachen glacier, Current Sci., 96(5), 646-648, 2009.

Vinnikov, K. Y., Grody, N. C., Robock, A., Stouffer, R. J., Jones, P. D., and Goldberg, M. D.: Temperature Trends at the Surface and in the Troposphere, J. Geophys. Res., 111, D03106, doi:10.1029/2005JD006392, 2005.

Winiger, M., Gumpert, M., and Yamout, H.: KarakorumHindukush-western Himalaya: assessing high-altitude water resources, Hydrol. Processes, 19(12), 2329-2338, 2005.

Xie, A. H., Ren, J. W., Qin, X., et al.: Reliability of NCEP/NCAR reanalysis data in the Himalayas/Tibetan Plateau, J. Geographical Sci., 17(4), 421-430, 2007.

Xu, J. Z., Hou, S. G., Qin, D. H., et al.: Dust storm activity over the Tibetan Plateau recorded by a shallow ice core from the north slope of Mt. Qomolangma (Everest), Tibet-Himal region, Geophys. Res. Lett., 34, L17504, doi:10.1029/2007GL030853, 2007.

Yao, T., Pu, J., Lu, A., Wang, Y., and Yu, W.: Recent glacial retreat and its impact on the hydrological processes on the Tibetan Plateau, China, and surrounding regions, Arct. Antarct. Alp. Res., 39, 642-650, doi:10.1657/1523-0430(07510)YAO2.0.CO;2, 2007.

Zou, C. Z., Goldberg, M. D., Cheng, Z., Grody, N. C., Sullivan, J. T., Cao, C., and Tarpley, D.: Recalibration of Microwave Sounding Unit for Climate Studies Using Simultaneous Nadir Overpasses, J. Geophys. Res., 111, D19114, doi:10.1029/2005JD006798, 2006. 